\title{
Effect of COVID-19 on Quick Service Restaurant Industry in China and the US
}

\begin{abstract}
Lin Li
Bentley University, Waltham, MA, 02452, the United States

*Corresponding author.Email: L2_LIN@bentley.edu

ABSTRACT

Since the worldwide breakout of COVID-19 pandemic, hundreds of thousands of people died and lost their jobs. The pandemic made almost all economies in recession, with negative GDP growth rate and high unemployment rate. As the top two biggest economies, China and the US are not immune to this pressure. The restaurant industry in these two countries, which is the very basic aspect of people to reflect consumption power, can be influenced significantly. Quarantine requirement prevents people from dining out, even ordering delivery. People and industries are frustrating about future economy growth. Therefore the purpose of this article is to provide information on the restaurant industry and quick service segment in both countries, trying to give out suggestions by investigating professional data and reports and conducting observations and interviews as these methodology can help explain the numbers on websites and could be realistic. Main data source for both countries will be the second-hand information published on the Internet. Observations and interviews will be conducted in China by the author and the objects will be traditional restaurants and their owners, especially quick service restaurant owners. Revenue loss, high unemployment rate, and increasing operational cost drag the quick service restaurant section into recession.
\end{abstract}

Keywords: Global economy, China, the US, Unemployment rate

\section{INTRODUCTION}

As COVID-19 virus wreaks havoc around the world since December 2019, countries are facing more serious problems regarding all aspects of development. This worldwide "virus world war" has hurt everyone to some extent. It is different from the financial crises happened in the 19th and early 20th centuries, which were all about money. COVID-19 not only destroyed a country's financial situation, but also took people's lives away. The worst thing for now, although countries have been struggling with it for almost one year, is that there has not appeared to have an efficient and safe antidote or any solutions to the virus. People are dying and the global economy is going down. The global economy is projected to contract by $4.4 \%$ in 2020 [1]. The global market for restaurant industry is estimated at $\$ 1.2$ trillion in the year 2020 and is projected to reach a revised size of $\$ 1.7$ trillion by 2027 , growing at a CAGR of $4.7 \%$ over the period 2020-2027 [2]. After being the only country with positive GDP growth in the third quarter, China continues to be the only economy in the world that shows positive growth in year 2020. Its GDP is projected to expand $1.9 \%$ this year [3]. The US appears to have negative growth rate since the start of COVID-19 and slowly recovers from the negative level to previous level until October 2021. High levels of unemployment and elevated savings rates damage spending later in 2020, leading to a much slower GDP expansion of only $1.5 \%$ in the fourth quarter. This results in a negative annual growth rate of $3.5 \%$ in 2020 . Recovering from the pandemic is not easy for every economy. Figure 1 shows the real GDP growth rate in 2020 around the world - many countries have slow or negative GDP growth [4]. 


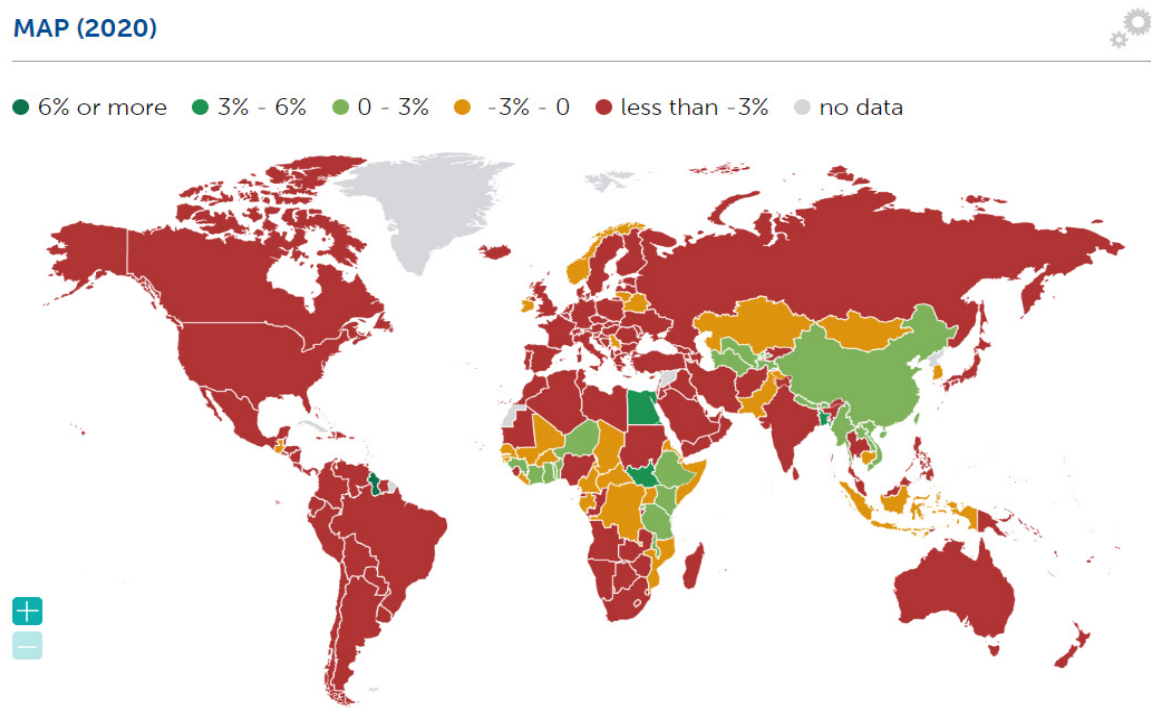

Figure 1 Projected real GDP growth in the world in 2020 [4]

This article will introduce overall profit trend in the restaurant industry and focuses more on the quick service section in the industry for these two countries. The main research questions include the overall effect of COVID-19 on the restaurant industry, the amount of revenue (in local currency) dropped due to COVID-19 in the quick service section, the main reason for the profit loss, the revenue projection be for the future, and the time necessary to make the restaurant industry and whole economy on the right track. By analyzing the information and giving some suggestions separately for China and the US, it would be more reasonable to predict other economic-related terms in a country, like employment rate, customer demand, and consumption power. Since every sector in a country is closely linked, one factor can influence others whenever and wherever possible. Thus, knowing one sector well helps to know others as well. In this process, national economy, or global economy trend would be more transparent although entire recovery of economy is not going to happen until late 2021 as countries need more time to take a breath from the pandemic.

\section{OVERVIEW OF THE ECONOMIC SITUATION IN CHINA AND THE US}

The literature review aims to present and compare the information and results from different research methods to see whether the conclusion stays consistent. The information here will include some established reports regarding to the development of the restaurant industry and quick service section in China and the US, results from observations, and findings from interviews. The International Monetary Fund recently turned slightly more positive on the global economy for this year, but warned of a "long, uneven and uncertain" recovery. The global economy is now projected to contract by $4.4 \%$ in 2020 [1]. The global market for restaurant industry estimated at $\$ 1.2$ trillion in the year 2020 and is projected to reach a revised size of $\$ 1.7$ trillion by 2027 , growing at a CAGR of $4.7 \%$ over the period 2020-2027 [2].

\subsection{China}

According to Deloitte, 94\% of interviewed restaurant companies declared that the operation is negatively affected by COVID-19 and $69 \%$ of them lost more than $80 \%$ customers [5]. According to iiMedia Research, the number of restaurants decreased to 9.414 million from around 11 million [6]. In the future six months, around $48 \%$ companies will need to finance their operation from investors more than 10 million RMB. From January to July in 2020, China's restaurant revenue reached 1.8 trillion RMB, which was lower than the confidence level due to the pandemic, but the increasing trend is stable and optimal. For the whole 2020 year, the total revenue of restaurant industry is expected to increase to 4.15 trillion RMB. Monthly unemployment rate increased to $6.2 \%$ in February from $5.3 \%$ in January and this indicator remained $5.7 \%$ in June as the pressure on unemployment is continuing [4].

Quick service restaurants in China play an important role in revenue earning. Quick service industry is one of the most rapid-growing industries in China. The market value decreased in this year to 982 billion RMB, but it is projected to increase to 1.1 trillion RMB in 2021 [7]. McDonalds, the biggest fast food company in the world, has a different story in China compared to KFC. KFC has around 10 thousand restaurants in China and its mother company, Yum! Brands, is optimal to have another 10 thousand restaurants open in the future. McDonalds has around 3100 restaurants in China, experiencing an accelerating localization. The secondquarter worldwide revenue for McDonalds decreased by 
$30 \%$ as Yum! Brands decreased by $3.12 \%$. The reason could be that McDonalds 'market size is larger than Yum! Brands, therefore, the amount of loss accounted more than that of Yum! Brands [8].

After being the only country with positive GDP growth in the third quarter, China continues to be the only economy in the world to show positive growth in year 2020. Its GDP is projected to expand 1.9 this year, according to the latest economic outlook released by the IMF. The expectation of positive performance of restaurant industry and quick service sector is reasonable for China.

\subsection{The United States}

The US economy suffered from an unprecedented contraction in the first half year due to the COVID-19 pandemic. In the second quarter, real GDP dropped $31.4 \%$, which was the worst percent change from preceding quarter in the recent five years. The economy recovered robustly in the third quarter. It grew at almost $35 \%$ as activity bounced back from COVID-19 lockdowns. Economic output rose $7.4 \%$ compared with the previous quarter, according to the metric used by many other advanced economies to report GDP. The increase in GDP indicated an increase in personal expenditure, which reflected the increase in goods and service. Since the breakout of the pandemic, keeping social distance and decreasing gathering made the economy stagnant. Increased GDP growth rate shows a positive sign of recovery.

The National Restaurant Association published the Restaurant Performance Index (RPI), a monthly composite index that tracks the health of and outlook for the U.S. restaurant industry, for September 2020 saying that the index number stood at 98.1 in September, increasing $0.6 \%$ from August, and accounted for the highest level since February (Figure 2) [9].

\section{Restaurant Performance Index}

Values Greater than $100=$ Expansion; Values Less than $100=$ Contraction

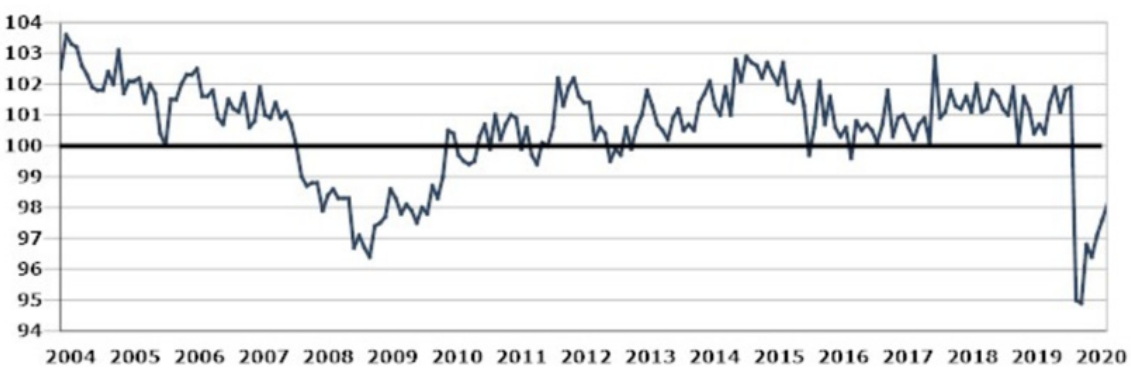

Figure 2 Restaurant performance index from 2004 to 2020 in the US [9]

The Expectations Index, measuring restaurant operators' six-month outlook for four industry indicators, stood at 99.5, going up $0.1 \%$ from the previous month. While the Expectations Index is inching closer to the 100 level, it continues to signal a high degree of uncertainty among restaurant operators about business conditions in the coming months. Consumer Confidence Index, changes in consumer sentiment, has a significant effect on household expenditure on discretionary items. During a recession, consumer demand for lower-priced value products from restaurants increases. The consumer confidence index is expected to decrease in 2020 , posing a potential threat to the industry [10].

In September, the restaurant sales went up $\$ 1.1$ billion (2.1\%) from August's seasonally adjusted volume of $\$ 54.5$ billion. Although it seemed to be a robust increase in normal times, it was only about half of the gains from July and August. Inefficient performance of the industry turned out a frustrating employment rate. Some indicators changed during this period. Full-service restaurant employment, still kept 2.3 million below pre-coronavirus levels, dropped significantly in April at the amount of about 5 million people. The quick service restaurant employment decrease about 1 million people during February and April 2020 and slightly recovered 0.7 million people during April and August 2020. Employment change remained negative for the whole industry with different sectors, including quick service and fast casual, cafeterias/grill buffets/buffets, snack \& non-alcoholic beverage bars, and mobile food service. Thirty-two states lost jobs in September. Massachusetts lost a net 7,900 eating and drinking place jobs in September tops among the 32 states that saw employment declines. Florida $(-4,600)$, Maine $(-3,800)$, Virginia $(-3,400)$ and Minnesota $(-3,300)$ also registered sizable restaurant job losses. Compared with February level, some states' employment was down more than $20 \%$ (Figure 3). Most states reported decreasing employment from the change of $0.1 \%$ to $19.9 \%$. Only three states recognized slightly increase in restaurant employment [11]. 


\section{September 2020 restaurant employment compared to February level}

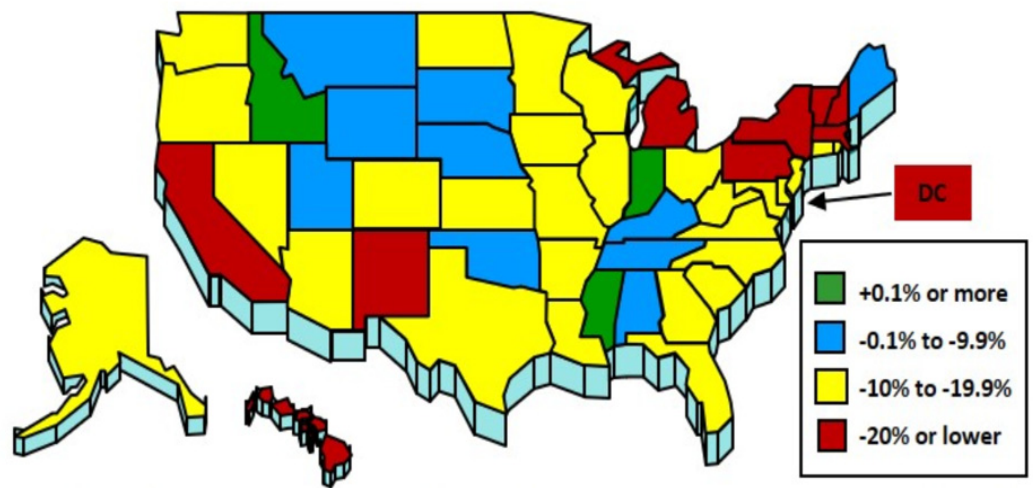

Figure 3 September 2020 restaurant employment compared to February level in the US [11]

Limited-service segment leads menu prices higher. In the months leading up to the pandemic, full-service menu-price growth had surpassed the $3 \%$ level for the first time since 2014 (Figure 4) [12].

Menu Prices, Grocery Store Prices \& Overall Consumer Prices

Percent change versus same month in previous year

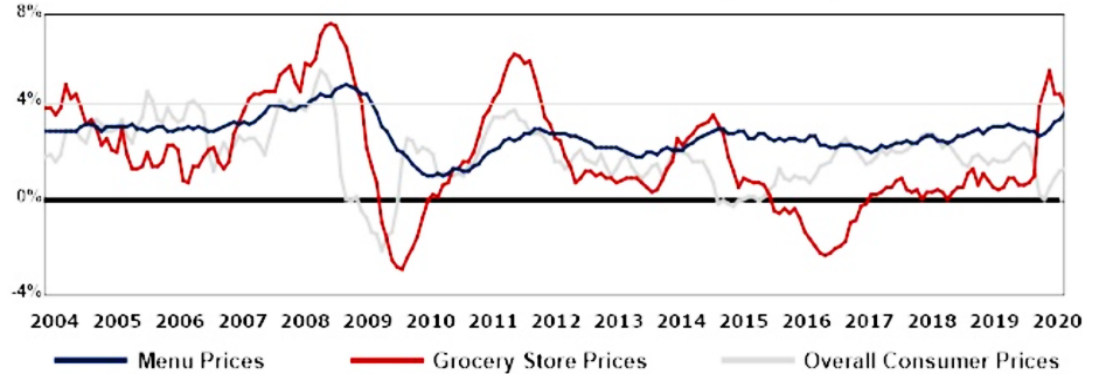

Figure 4 Prices percent changes versus same month in the previous year in the US [12]

These indicators reflect the volatility of the year and uncertainty for the future. Although RPI shows an increasing trend, the economy is still in the contraction situation. High unemployment rate and explosively increasing prices tell us how severe the COVID-19 pandemic is. It not only made people sick and die but also contracted an economy in many aspects.

Quick service restaurants contribute a lot for the US's economy. All of the top ten fast-food brands globally in 2019 have their roots in the United States. According to Statista, the fast food industry yearly revenue in the United States has grown by almost $\$ 90$ million over the last decade. The industry provided job positions making the number of people employed in this industry increased by $35 \%$ since 2010 . The total revenue of the QSR industry in the US reached 273 billion dollars in 2019 and was predicted to drop to 239 billion dollars in 2020 as a result of the COVID-19 pandemic. The figure 5 showed a forecast of the US economy in 2020 and 2021. US appears to have negative growth rate since the start of COVID-19 and slowly recovers from the negative level to previous level in October 2021 [13]. According to the latest new, the US unemployment claims rose to 778,000 in the week of November 18th, 2020 [14]. High levels of unemployment and elevated savings rates damage spending later in 2020, leading to a much slower GDP expansion of only $1.5 \%$ in the fourth quarter. This results in an annual growth rate of $3.5 \%$ in 2020 . 


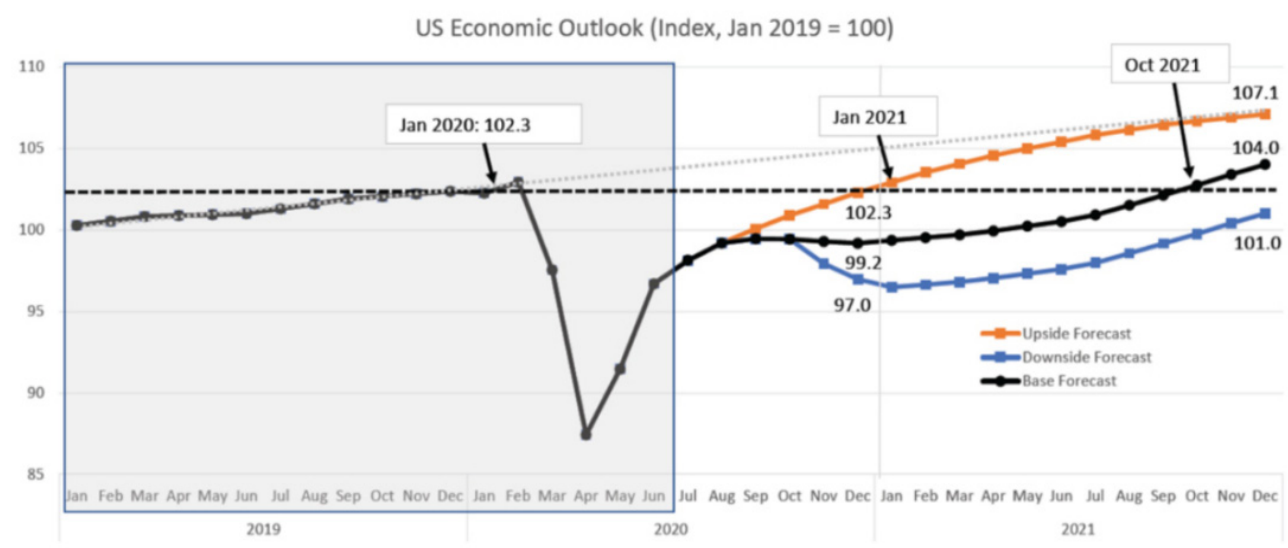

Figure 5 The US economic forecast for 2020 and 2021 [13]

Overall, the global economy is not doing well, which would absolutely have negative effect, more or less, on every economy in the world. the restaurant industry and quick service sector in both countries are losing money due to the pandemic. Revenue dropped dramatically and turned out a sudden increase in unemployment rate in the first half year because of the closure of general restaurants and quick service restaurants. Different actions in two countries led to different results. For example, wearing mask is required in China but optional in the US. Facing a fatal disease, one efficient way to prevent from infecting is to wear mask. It turned out that COVID-19 has been controlled safely in China but the confirmed cases in the US is still rising. The difference leads to different time needed to recover from the previous period. Recovering is not only for the financial numbers going up, but also for other economic indicators like unemployment rate, price level, and customer demand. Waiting for all or most indicators to show positive signs is not optimal for this and the coming years.

\section{METHODOLOGY}

\subsection{Observation}

Back in late January 2020, Chinese government published several policies fighting the war. The most influential one was to lockdown Wuhan city to prevent the communication with other regions by asking all citizens to stay at home. No gathering is allowed. Only one person of a family could go out twice a week and must have mask on. This policy directly influenced the number of customers who would dine out, because almost on body would. Even the restaurant owners must stay at home to protect others and themselves from the virus. This required action lasted for a month and people could go out but still with the mask on. However, most restaurants were afraid of reopening, therefore they remain closed until early March. Only within this quarantine month, many small restaurants fell down because of no revenue inflow. Small restaurants along the streets closed and many people lost jobs. Some restaurants reopened but only a few customers walked in. Quick service restaurants like KFC and McDonalds suffered the same situation as other types of restaurants. Until late March, malls reopened, as well as other restaurants in the mall. Each province had different limitations of communication in the city. For those which reported all confirmed cases were in the hospital, people are allowed to dine out with the mask on. For cities that were much more serious, people were afraid to go out. Around May, all cities were claimed as lowrisk regions, which meant people could travel elsewhere within China. All types of restaurants went back to the right path. Due to Chinese government's strict action, cases imported from overseas got caught before they entered. The possibility of the second large-scale boom of virus is considered to remain low, according to Nanshan Zhong. China operated normally until now and seemed to control all confirmed cases in safe. Therefore, restaurants are recovering from the recession period in the early year.

Some observers in the US suggested that there is no required closure for restaurants. Some restaurants kept open during this hard time, but profit went down for sure. As the number of confirmed cases in the US increases, more and more people are aware of the importance of self-protection. They choose not to go out for dinning. However, the situation is different from states to states. For example, Massachusetts local government took actions, like curfew, to control the confirmed rate of $1.4 \%$ per fourteen days. California and Texas ranked top two states with the most confirmed cases, which officially considered more than 910,000 cases.

\subsection{Interview}

Owners of quick service restaurants and general fullservice restaurants were interviewed. Interview 
questions aim to discover what owners exactly feel during this hard time. It could be more realistic than numbers to reflect the effect of COVID-19. The interview took place in the late September, so the managers answered questions after taking the current condition and government action into account. Questions and brief results are shown in this part. Details are discussed in the Results and Discussion part.

\subsubsection{Quick service restaurants}

The article selected KFC and McDonald's as representatives of fast food restaurants in China. 60 KFC and McDonald's restaurants' top managers in different cities in China were interviewed via email. Interview questions are listed below:

-How would you rate the restaurant's performance during this pandemic in the scale of 5? (1 as the lowest performance and 5 as the highest)

-What did you observe the most different before and after COVID-19 in terms of customers?

-What do you expect in next three months?

\section{INTERVIEW RESULTS OF 60 QUICK SERVICE RESTAURANT OWNERS}

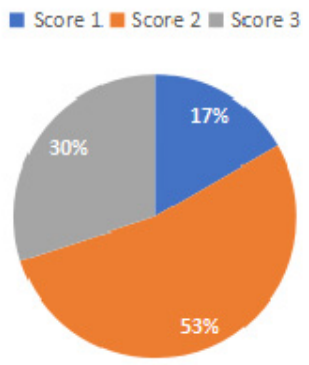

Figure 6 Performance scores given by 60 quick service restaurant owners

\subsubsection{Full-service restaurants}

80 general restaurant (not include fast food restaurant) owners were interviewed and 52 of them responded. For general restaurants, interview questions are as follows:

-How would you describe the difference before and after COVID-19 pandemic in terms of customers, revenue, and operating costs?

-What was the restaurant's market value before COVID-19? How did it change afterward?

-What was the most challenging thing for you to operate the restaurant during this hard time?
Table 1 Effects of COVID-19 on 52 full-service restaurant managers

\begin{tabular}{|lll|}
\hline \multicolumn{2}{l}{ \# of manager } \\
Effect & reported & $\%$ of total \\
\hline $\begin{array}{l}\text { Revenue dropped }>= \\
10 \%\end{array}$ & 52 & $100 \%$ \\
\hline Layoff & 39 & $75 \%$ \\
\hline Death of relatives & 7 & $13.46 \%$ \\
\hline
\end{tabular}

\section{RESULTS AND DISCUSSION}

\subsection{Quick Service Restaurant Interview Results}

Among 60 respondents, $17 \%$ of them are from Wuhan city, which was the most severe province in China during COVID-19. Almost all of them suffered from the virus and gave 1 for the performance level. $53 \%$ of them rated the performance as 2 . These people are from cities nearby, recognizing how terrible when the COVID-19 pandemic started and became worse. During the mandatory quarantine month, nothing opened and remained closed for a month. Quick service restaurants like KFC and McDonald's are the most popular among teenagers and children. However, these managers stated that they had not seen even one family coming with children one month after the closure of mandatory quarantine. $30 \%$ of them gave 3 , the highest score among these people. These managers are managing larger storefront. These restaurants located in the central areas in the major cities. Typically, they have larger customer base than those located far away from the center or in the small provinces. Since the revenue base is larger, the managers remained positive for the future during the pandemic period, therefore, they gave the highest score among the respondents. Like the general restaurants, fast food restaurants had to shut down during the hardest period when COVID-19 spreading nationwide in China. Managers rated the performance not only based on the revenue, but also how they felt during that time. Higher score does not mean they performed better than others but indicated that these managers are confident about the operation after the pandemic. In March, slightly more customers ordered for delivery but it was still at a very low level compared with normal time. After late March, most malls and restaurants reopened for customers and more people felt save to dine out. The quick service restaurants started recovering from the previous period. Until early November, all 60 managers expected to have revenue increased due to the restrict control of COVID19 by the Chinese government.

The biggest difference acknowledged by managers is the number of customers walking in, which shows coherence with results from that of general restaurants and other data regarding the industry. All of them 
remained positive about future operation in China. The spread of COVID-19 is totally under control due to the strict supervision for every person who come to China as well as careful investigation of all close contacts.

\subsection{Full-service Restaurant Interview Results}

The answers to the first question from all respondents follow the same trend. The main idea of their answers is that there was a significant customer drop during the early months of this year, when the pandemic started to roll in. During the shut-down period, all people were required to stay at home. There could not even find a person in the street at that time. "Revenue will go down for sure." This was what they said the same in their answers. $75 \%$ of these owners stated that, although it becomes normal, the restaurant is still trying to recover the loss from previous period. They chose to increase their prices to offset some losses, but they found it hard because people do not have money right now. Therefore, they would choose somewhere cheap. Operating costs raise because ingredients prices went up as demand went down. This phenomenon turned out the same result of classic economic principle. On the demand curve, quantity and price are inversely related, which suggested that if demanded quantity of a product goes down, its price will go up. Now everyone is reopening their restaurants, so they need to buy ingredients. As the supply of a product goes up, its price goes up as well.

All 52 owners illustrated that their market value has dropped by more than $10 \%$ than before. As the revenue dropped, owners did not enough cash to pay for the employee cost. Either large or small layoffs were reported by 39 of them. Additionally, 7 of them reported death of families and friends in the early stage of COVID-19, stating that the bad emotion negatively influences their operations.

\subsection{Discussion}

Recovery for each economy is a difficult and timeconsuming path. In China, COVID-19 led thousands of job loss and death of people. Customer purchasing power went down and demanded was less than the last year. Around 460 thousand companies, large capital size and small capital size, went bankrupt in the first quarter. China achieved positive growth in the third quarter, which indicated that it is on the right track. Reopening the economy stimulates customers' consumption, which is a good news for the restaurant industry and quick service sector. The economy is projected to continue growing in 2021. As the whole economy becomes more optimal, the restaurant industry and quick service sector can take advantage of achieving recovery from the pandemic. Until now, in the US, there are 9.83 million confirmed cases and 237 thousand people died [15].
Because of the president election 2020, people gathered together to support their winner, the cases are expected to increase in these days. If COVID-19 cannot be controlled, it can continue hurting the economy, including the industries within it. Unemployment rate will continue to increase. Human resource is important to a country. If the number of people continued deceasing, the cost of human resource will be much more expensive. The cost of production will also rise. This would not be a healthy sign of an economy. Recovering in 2021 is not realistic for the US and it could take longer time for them to cure themselves from the COVID-19.

Restaurant industry is lagging indicator of the economy. In other words, it performs better after the economy boom because people got money from the expansion, so their consumption power increases. Both countries' quick service restaurants were negatively influenced by COVID-19 at the beginning of the year. However, China's strict policy over the COVID-19 pandemic helped to make the situation better. Restaurants, including quick service restaurants, started to reopen in the March and the operations become normal now [16]. Managers stayed optimal for the future operation and emphasized the importance of epidemic prevention in the restaurant-spraying disinfectant fluid, wearing mask, and measuring temperature for employees and customers. The truth is that every opening restaurant, no matter full-service or quick service, is required to do such protecting work. This protection not only makes employees safe but also makes customers feel safe and relaxed to come to the restaurant under such a stressed condition. This is why Chinese managers are expecting better performance in China in the future. Vaccinations are on the way. What we can do now is to protect ourselves. Actions taken by Chinese restaurants are recommended to the restaurants in the US. The article did not include the observation and interview in the US, so what the article relies on are just numbers and reports from government. Therefore, the truth may be different in different states or even different areas within the same state. The author would do further work in the US in May 2021. The interview and observation conducted in China also have some drawbacks. Due to time limitation, data from these provinces cannot represent the whole. Although KFC and McDonalds occupy large portion of the market, there are still other local quick service restaurants that were heavily affected by the COVID-19. They may suffer more than these big brands because of small size and insufficient cash flows. However, it is obvious to all that the pandemic negatively affected the whole restaurant industry. When the economy starts to recover from the COVID-19, the quick service restaurant section will also recover from the past expecting higher profit and increasing customer number. 


\section{CONCLUSION}

The quick service restaurant section is negatively affected as the whole restaurant industry did. Revenue loss, unemployment, and increasing operational cost drag the quick service restaurant section into recession. According to the different actions taken by China and the US, how and when the economy will recover fully could be different, as well as the change in economic indicators like unemployment rate and RPI. As China outperformed many countries during COVID-19, it could be easier and take less time for China to offset the loss in this period. After the president election, everything is a new start. However, Biden promising to take serious action to control the spread of the virus is good news for America.

\section{ACKNOWLEDGMENT}

I am sincerely thankful to the restaurant managers who respond to my interview questions with patience, which helped me understand how they felt about the COVID-19 pandemic and its downside effects. I also want to thank librarians at Bentley helping me get access to some articles and magazines containing wonderful information. Last but not the least, I'm thankful to Professor Frank R. Lichtenberg, PhD., Columbia University, for introducing economic principles and methodology for paper writing.

\section{REFERENCES}

[1] S. Amaro, October 13th, 2020, IMF revises its global GDP forecast higher, but warns the economy 'remains prone to setbacks', retrieved from https://www.cnbc.com/2020/10/13/imfworld-economic-outlook-2020-amid-coronaviruscrisis.html, accessed on November 8th, 2020

[2] Research and Markets, September 21st, 2020, Global Full-Service Restaurants Industry (2020 to 2027) - Market Trajectory \& Analytics, retrieved from https://www.prnewswire.com/newsreleases/global-full-service-restaurants-industry2020-to-2027-market-trajectory-analytics301134845.html\#: :text=Amid\%20the\%20COVID $\% 2$ D19\%20crisis,over\%20the\%20period\%202020 $\% 2$ D2027, accessed on November 8th, 2020

[3] CGTN, October 19th, 2020, China to be the only economy with positive growth in 2020, says IMF report, retrieved from https://news.cgtn.com/news/2020-10-13/WorldGDP-to-drop-4-4-in-2020-IMF-UyNuoUIFlC/index.html, accessed on November 8th, 2020

[4] IMF, Real GDP Growth, retrieved from https://www.imf.org/external/datamapper/NGDP_
RPCH@WEO/BRA?year=2020, accessed on November 23rd, 2020

[5] Deloitte, March 2020, The impact of COVID-19 on China's catering industry's finances and operations Impact research report, retrieved from https://www2.deloitte.com/content/dam/Deloitte/cn /Documents/consumer-business/deloitte-cn-cbnew-pattern-of-cartering-consumption-zh200327.pdf, accessed on November 8th, 2020

[6] The restaurant industry analysis report, May 29th, 2020, retrieved from https://www.iimedia.cn/c1061/71699.html, accessed on November 9th, 2020

[7] China Business Industry Research Institute, September 3rd, 2020, retrieved from https://m.askci.com/news/chanye/20200903/16565 61205337.shtml, accessed on November 9th, 2020

[8] Sina finance, July 31st, 2020, McDonald's secondquarter performance fell more than Yum, retrieved from https://finance.sina.com.cn/roll/2020-0731/doc-iivhvpwx8521683.shtml, accessed on November 9th, 2020

[9] Restaurant.org, Restaurant Performance Index, retrieved from https://restaurant.org/research/economy/rpi, accessed on November 11th, 2020

[10] IBIS World, Fast Food Restaurants in the US, retrieved from https://my-ibisworldcom.ezp.bentley.edu/us/en/industry/72221a/industr y-performance, accessed on November 9th, 2020

[11] Restaurant.org, Thirty-two states lost restaurant jobs in September, retrieved from https://restaurant.org/articles/news/thirty-twostates-lost-restaurant-jobs, accessed on November 11 th, 2020

[12] Restaurant.org, Menu Prices, retrieved from https://restaurant.org/research/economy/indicators/ menu-prices, accessed on November 11th, 2020

[13] The Conference Board, The Conference Board Economic Forecast for the US Economy, retrieved from https://www.conference-board.org/research/usforecast\#: : :text=Base $\% 20$ Case $\% 20$ Forecast $\% 3 \mathrm{~A}$, GDP\%20rebound\%20of\%2034.6\%20percent.\&tex $\mathrm{t}=$ This\%20results\%20in\%20an\%20annual,3.5\%20 percent $\% 20$ growth $\% 20$ in $\% 202021$, accessed on November 12th, 2020

[14] S. Chaney Cambon, November 25th 2020, U.S. Unemployment Claims Rose to 778,000 Last Week, retrieved from 
https://www.wsj.com/articles/weekly-jobless-

claims-coronavirus-11-25-2020-11606249439,

accessed on November 29th 2020

[15] CDC, retrieved from https://covid.cdc.gov/coviddata-tracker/\#cases_casesinlast7days, accessed on November 8th, 2020

[16] The Paper, September 1st, 2020, China's Catering Big Data Report in the First Half of 2020, retrieved from

https://www.thepaper.cn/newsDetail_forward_896 8918, accessed on November 9th, 2020 